\title{
A systems approach to evaluate research requirements for animal production in south-east Mexico
}

\author{
S. Anderson, J. Santos and R. Boden \\ Facultad de Medicina Veterinaria y Zootecnia, Universidad Autonoma de Yucatan, \\ Apartado 116-4, Merida, Yucatan, Mexico
}

\section{Introduction}

The correct identification and evaluation of technical and socio-economic constraints to livestock production in developing countries is crucial for the development of research/extension programmes. Throughout the developing world because resources for research/extension are very limited wastage should be minimized. Thus a systematic approach to the identification and evaluation of constraints is required. Research/extension strategies such as 'farming systems research,' on-farm trials, participatory development, etc., have been developed with the aim of improving the effectiveness of research/extension work by researchers and farmers working in crop-based systems and little as yet has been done to apply a 'systems' approach to the evaluation of the research needs of livestock systems or the livestock component of mixed systems (Tripp and Woolley, 1990). At the Faculty of Veterinary Medicine and Animal Production of the Autonomous University of Yucatan (FMVZ-UADY) in Mexico it was decided to use a 'systems' approach to evaluate the problems existing in the regional animal production systems to derive research and teaching priorities for the faculty, and to monitor the use of improved animal production technology by farmers.

\section{Methods}

The FMVZ-UADY work has concentrated so far on the predominant species of the animal production system in south-east Mexico which is cattle. Official statistics on cattle production differ widely between sources and it was necessary to establish a baseline data set initially. The methodology used to evaluate cattle production systems is summarized as follows: selection of area of study (cattle production in the state of Yucatan); collection and processing of all documented information available; statistical survey of cattle farms (all production systems) in the state (no. = 224 approx. 10\%); evaluation of static survey data and selection of system (dual-purpose) upon which to concentrate work; pilot dynamic survey of dual-purpose cattle production (1 year); full dynamic survey ( 2 years minimum); evaluation of dynamic data, identification of systems' constraints, farmer innovations and research needs; and planning of research and continued systems monitoring.

The methodology of the pilot and dynamic surveys differs from previous work (see RISPAL, 1988) in that it has been designed to allow the collection of bioeconomic data for individual animals. The advantage being that the system can thus be evaluated at various levels down to the individual animal. The use of herd figures for reproductive rate, milk production or calf growth for example is not sufficiently sensitive to identify some production problems.

\section{Results}

Statistical survey

Some of the characteristics and numbers of farms surveyed for the six systems identified in the statistical survey are presented in Table 1. From a multivariate analysis it was found that the main characteristics that distinguished farms were those of feeding management, employment of temporary labour and cattle genotypes. The second level of differentiation between farms included the factors of whether or not the farmer had another source of income, whether animals were pastured in lots and whether technical assistance was available to the farmer. None of the variables recorded was highly correlated suggesting that each was a useful piece of information. The results showed that a lot of variation existed between systems (and farms within systems) in terms of resources and operational characteristics. The dual-purpose system (DP) was most common among small farmers and the system most intensively managed. It was decided to study DP further because the farms were small to medium size and because DP is the only system capable of producing milk based on local resources (Yucatan is 
only $15 \%$, and Mexico $45 \%$, self sufficient in milk and milk products). Also access to credit and technical assistance was found to be limited to this group and the DP farms were generally the only source of income for the farmers.

\section{Pilot dynamic survey}

Eight DP farms were studied during the pilot dynamic survey. From a least-squares analysis of performance per cow the following variables were found to affect significantly milk offtake and therefore may be considered as areas for further research: numbers of milkings per day; month of lactation; lactation number; cow genotype; suckling management; body condition; mastitis level. A similar analysis was carried out for cow reproductive efficiency. A summary of the across-farm mean economic parameters calculated during the 1st year of the survey is presented in Table 2.

\section{Conclusions}

From the statistical survey results different characteristics of the cattle production systems such as level of intensification and resource use were evaluated. It was concluded that the DP system merited specific attention. The monitoring of the DP system over a 12-month period allowed the testing of methodology of dynamic surveys at per animal and farms levels. It was concluded that per-animal monitoring was essential to identify biological constraints in the system due to the variation between animals and the importance of the interactions between management strategies and biological processes that cannot be estimated from herd averages. Preliminary results suggest that important constraints to the system exist in the marketing of milk and animals and in the subutilization of local resources for food which concurs with the findings of Nicholson (1990) from Venezuela. Biological constraints identified that require further investigation were the effects of suckling on dam reproductive efficiency and milk offtake, the effect and cconomic importance of mastitis, and the use of alternative supplementary foods.

The methodology for cattle production systems evaluation employed in this survey has facilitated the identification and characterization of the important production systems, the generation of data

Table 1 Farm characteristics of the cattle production systems identified in the statistical suro'y

\begin{tabular}{|c|c|c|c|c|c|c|c|}
\hline & \multicolumn{6}{|c|}{ Systemt } & \multirow[b]{2}{*}{ Total } \\
\hline & DP & SB & PB & WP & WF & D & \\
\hline $\begin{array}{l}\text { No. } \\
\%\end{array}$ & $\begin{array}{l}38 \\
17\end{array}$ & $\begin{array}{l}53 \\
23 \cdot 5\end{array}$ & $\begin{array}{l}23 \\
10\end{array}$ & $\begin{array}{l}54 \\
24\end{array}$ & $\begin{array}{l}53 \\
23 \cdot 5\end{array}$ & $\begin{array}{l}4 \\
2\end{array}$ & $\begin{array}{l}224 \\
100\end{array}$ \\
\hline $\begin{array}{l}\text { Principal products } \\
\text { Mean livestock } \\
\text { units per farm (s.e.) }\end{array}$ & $\begin{array}{l}\text { Milk } \\
\text { Meat } \\
59(8)\end{array}$ & $144(29)$ & $\begin{array}{l}\text { Breeding- } \\
\text { stock } \\
208(54)\end{array}$ & $\begin{array}{l}\text { Weaned } \\
\text { calves } \\
74 \text { (12) }\end{array}$ & $\begin{array}{l}\text { Meat } \\
63(9)\end{array}$ & $\begin{array}{l}\text { Milk } \\
\text { Livestock } \\
80(13)\end{array}$ & \\
\hline $\begin{array}{l}\text { Median farm } \\
\text { area (ha) }\end{array}$ & 49 & 158 & 225 & 64 & 106 & 65 & \\
\hline Resource use & $\begin{array}{l}\text { Pasture } \\
\text { Suppl. food } \\
\text { Electricity } \\
\text { Labour }\end{array}$ & $\begin{array}{l}\text { Pasture } \\
\text { Suppl. food } \\
\text { Labour }\end{array}$ & $\begin{array}{l}\text { Pasture } \\
\text { Suppl. food } \\
\text { Labour }\end{array}$ & Pasture & Pasture & $\begin{array}{l}\text { Pasture } \\
\text { Suppl. food } \\
\text { Electricity } \\
\text { I_abour }\end{array}$ & \\
\hline
\end{tabular}

+ $\mathrm{DP}=$ dual-purpose, $\mathrm{SB}=$ suckler beef, $\mathrm{PB}=$ pedigree breeders, $\mathrm{WP}=$ weaner producers, $\mathrm{WF}=$ weaner fatteners, $\mathrm{D}=\mathrm{dairying}$.

Table 2 Across farm mean economic parameters from pilot dynanic survey of dual-purpose cattle farms

\begin{tabular}{|c|c|c|c|c|c|c|c|c|c|c|}
\hline & \multirow{2}{*}{$\begin{array}{l}\% \text { herd } \\
\text { milked }\end{array}$} & \multirow{2}{*}{$\begin{array}{c}\text { Milk offtake } \\
\text { per cow } \\
\text { in herd (l/day) }\end{array}$} & \multicolumn{4}{|c|}{$\%$ of total operation costs } & \multicolumn{2}{|c|}{$\begin{array}{l}\text { Herd income } \\
\text { ( }(\text { /month) }\end{array}$} & \multirow{2}{*}{$\begin{array}{c}\% \text { Total } \\
\text { income } \\
\text { from milk }\end{array}$} & \multirow{2}{*}{$\begin{array}{l}\text { Total gross margin } \\
\text { per cow in herd } \\
(£ / \text { month })\end{array}$} \\
\hline & & & Food & Labour & Energy & Health & Milk & Animal & & \\
\hline Mean & 67 & $4 \cdot 70$ & 59 & 25 & 12 & 3 & $766 \cdot 4$ & 232.2 & 74 & 20.8 \\
\hline s.e. & 6 & 0.68 & 3 & 3 & 1 & 0.3 & $196 \cdot 8$ & 25.8 & 4 & $13 \cdot 6$ \\
\hline
\end{tabular}


and information for teaching purposes, the prioritization of systems for further research, the evaluation of productivity at the animal and herd levels and the identification of the important biological and socio-economic system constraints.

\section{Acknowledgements}

The financial support of this work by the Overseas Development Administration (UK), and the Natural Resources Institute are gratefully acknowledged.

\section{References}

Nicholson, C. P. 1990. An optimization model of dual purpose cattle production in the humid lowlands of Venezuela. MSc Thesis, Cornell University.

RISPAL. 1988. Report of the eighth general meting of the Latinamerican Research Network in Animal Production Systems (RISPAL), Guatemala.

Tripp, R. and Woolley, J. 1990. Training in farming systems research: review and prospects. Experimentnl Agriculture 26: 247-262. 